\title{
Radium Isotopes in an 0il-Field Produced Lake near Baku, Azerbaijan
}

\author{
Famil Yusif Humbatov*, Bahruz Allahverdi Suleymanov, Majid Mirza Ahmedov, \\ Valeh Saleh Balayev \\ Institute of Radiation Problems, National Academy of Sciences of Azerbaijan, Baku, Azerbaijan \\ Email: "humbatov@azecolab.com
}

Received 22 June 2016; accepted 6 August 2016; published 10 August 2016

Copyright @ 2016 by authors and Scientific Research Publishing Inc.

This work is licensed under the Creative Commons Attribution International License (CC BY). http://creativecommons.org/licenses/by/4.0/

(c) (i) Open Access

\section{Abstract}

An assessment of radiologically enhanced residual materials generated during oil and gas production in near Baku, Azerbaijan, was conducted. Distribution of the ${ }^{228} \mathrm{Ra} /{ }^{226} \mathrm{Ra}$ Activity Ratio (AR) with depth in a sediment core from radium lake was examined. The dashed line represented ingrowth assuming that ${ }^{228} \mathrm{Ra}$ was below equilibrium with ${ }^{232} \mathrm{Th}$ in the young sediments near the top and reached equilibrium at a depth around $10 \mathrm{~cm}$. In this study the radium isotopic data are used to provide estimates of the age of formation of the radiobarite contaminant and age of oil field lake. The results indicate that, the upper two layers in the core (up to $4 \mathrm{~cm}$ ) contain fallout ${ }^{137} \mathrm{Cs}$ so at least these layers are no older than about 40 yrs. Formation waters that are sent to disposal ponds may consist of accumulated heavy hydrocarbons, paraffin, inorganic solids, and heavy emulsions. We report here results of chemical and radiochemical measurements from formation waters separated from oil pumped from approximately $700 \mathrm{~m}$ below ground near Baku, Azerbaijan. Our results also include data from a formation water storage pond ("radium lake") where the waters are temporarily stored after oil is separated and then eventually disposed of by pumping into the Caspian Sea. We also analyzed the associated sediment for radiochemical components. Our study was intended to investigate how radium fractionated between the pond water and sediments.

\section{Keywords}

Oil Industry, Formation Water, Sediments, Radium Isotopes, NORM, Azerbaijan

\section{Introduction}

Oil and gas production and associated processing operations often result in the accumulation of Naturally-Oc-

${ }^{*}$ Corresponding author. 
Curring Radioactive Material ("NORM” or "TENORM" if technologically enhanced) at elevated concentrations in by-product waste streams. The ultimate sources of most of the radioactivity are from daughter products of uranium $\left({ }^{238} \mathrm{U},{ }^{235} \mathrm{U}\right)$ and thorium $\left({ }^{232} \mathrm{Th}\right)$ that are naturally present in subsurface formations from which oil and gas are produced. NORM, in the form of scale, has been known for many years to occur in some oil and gas pipelines. Deep formation waters, often with high total dissolved solids, tend to be enriched in natural radium isotopes. When these fluids are brought to the surface, $\mathrm{CO}_{2}$ may escape, resulting in a $\mathrm{pH}$ rise with the solubility products of many sulfate and carbonate species being exceeded. The result is often precipitation of scale deposits rich in the divalent alkaline earths $\mathrm{Ca}^{2+}, \mathrm{Ba}^{2+}, \mathrm{Sr}^{2+}$, and $\mathrm{Ra}^{2+}$ (Wilson and Scott, 1992; Mackay and HeriotWatt, 2003; Efendiyev, 1953) [1]-[3]. Radium, and its decay products, can occasionally be concentrated enough to be of human health concern because of their gamma radiation (Bernhardt et al., 1996; Smith et al., 1996) [4] [5]. It is estimated that each year in the oil/gas industry between 300,000 and 1,000,000 metric tons of NORM scale are produced (Tomson et al., 2003) [6]. The primary radionuclides of concern in NORM wastes are ${ }^{226} \mathrm{Ra}$ $\left({ }^{238} \mathrm{U}\right.$ series), and ${ }^{228} \mathrm{Ra}\left({ }^{232} \mathrm{Th}\right.$ series$)$ as well as their respective daughters.

The production waste streams most likely to be contaminated by elevated radium concentrations include produced water, scale, and sludge. Spills or intentional releases of these waste streams to the ground can result in NORM-contaminated soils that may need to be disposed. Since radium is fairly soluble in saline waters, it can follow the produced water stream and accumulate in formation water storage ponds rather than all being retained in scale deposits. Thus, dissolved radium in formation waters either remains in solution in the produced water, precipitates out in scales or sludges, or is removed from the produced water during storage (e.g., precipitation, adsorption onto sediment components). Conditions that effect radium solubility and precipitation include water chemistry (primarily salinity), temperature, and pressure (Jens and Sebastian, 2002) [7].

NORM contamination of scale and sludge can occur when dissolved radium coprecipitates with other alkaline earth elements such as barium, strontium, or calcium. In the case of scale, the radium coprecipitates primarily with barium, to form hard insoluble sulfate deposits (barite) (Doerner and Hoskins, 1925) [8]. Such scale typically forms on the inside of piping, filters, injection wellhead equipment, and other water handling equipment, but also can form as a coating on produced sand grains. In the case of sludge, radium can be present in several forms. It can coprecipitate with silicates and carbonates that form in the sludge, or it can be present as particles of barium sulfate scale that become incorporated into the sludge. NORM-contaminated sludge can accumulate inside piping, separators, heaters and other types of treatment facilities, storage tanks, and any other equipment where produced water is handled.

Formation waters that are sent to disposal ponds may consist of accumulated heavy hydrocarbons, paraffin, inorganic solids, and heavy emulsions. We report here results of chemical and radiochemical measurements from formation waters separated from oil pumped from approximately $700 \mathrm{~m}$ below ground near Baku, Azerbaijan. Our results also include data from a formation water storage pond ("radium lake") where the waters are temporarily stored after oil is separated and then eventually disposed of by pumping into the Caspian Sea. We also analyzed the associated sediment for radiochemical components. Our study was intended to investigate how radium fractionated between the pond water and sediments. Radium isotopes and some of their decay products have been used to date young barites deposits on the lake floor and radioactive barites at contaminated sites within oilfields production sites (Zielinski, Otton and Budahn, 2001) [9]. The average age of radioactive barites ( $<40$ years) can be estimated by comparing the present measurement activity ratio of $\left({ }^{228} \mathrm{Ra} /{ }^{226} \mathrm{Ra}\right.$ ) to that of the initial activity ratio $\left({ }^{228} \mathrm{Ra} /{ }^{226} \mathrm{Ra}\right)_{0}$ (Zielinski, Otton and Budahn, 2001) [9], provided that the radium isotopes incorporated into an insoluble radium mineral approximates a chemically closed system since the time of its formation. In present studies, the ratio is determined from the direct radioactivity measurement of the sediment samples, while the initial activity ratio of $\left({ }^{228} \mathrm{Ra} /{ }^{226} \mathrm{Ra}\right)_{0}$ is estimated by measuring the radium isotopes in modern produced water.

\section{Study Site and Experimental}

We have chosen a study location that represents one of the original sites for oil production in Azerbaijan (operated by Surachany PGOM, Petroleum Gas Obtaining Management). This site is located in the southeast portion of the Absheron Peninsula, near the capital city of Baku (Figure 1).

The petroleum began to be extracted at this site from the beginning of the last century (1907 with other sites in this area developing since 1912) (Alizadeh and Akhmedov, 1966) [10]. 


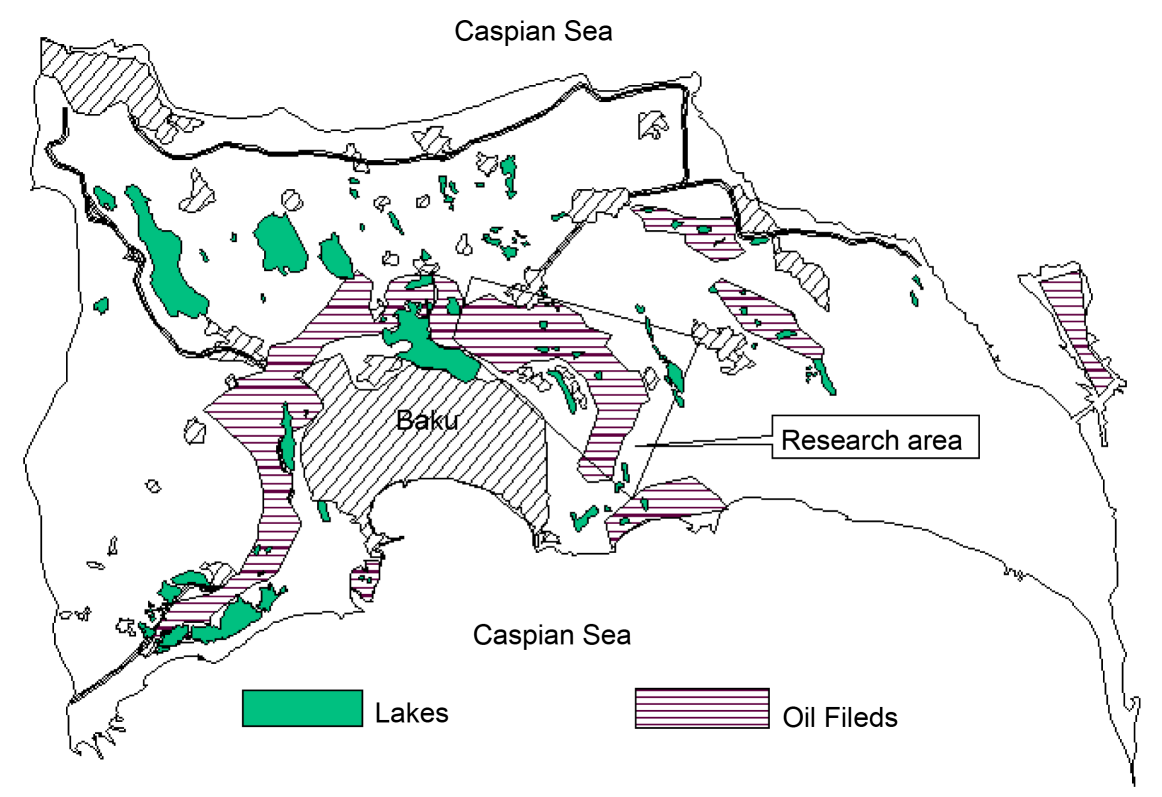

Figure 1. Map of Absheron peninsula showing site of oil field lake. (This site is located in the southeast portion of the Absheron Peninsula, near the capital city of Azerbaijan Republic-Baku. The petroleum began to be extracted at this site from the beginning of the last century-1907, with other sites in this area developing since 1912).

In recent years, the level of the deposits has been falling in the Surachany region requiring deeper drilling with lower grade deposits (higher percentage of formation water). At this site, as well as on other areas of the Absheron Peninsula some tens of hectares of polluted territories and lakes of petroleum origin are known to exist.

We collected samples of lake water, lake sediments, and formation waters from 7 different oil wells that surround the radium lake. All water samples were analyzed for major and minor cations ( $\mathrm{Na}, \mathrm{K}, \mathrm{Ca}, \mathrm{Mg}, \mathrm{Sr}, \mathrm{and} \mathrm{Ba}$ ) by atomic absorption spectrophotometry and anions $\left(\mathrm{Cl}, \mathrm{HCO}_{3}, \mathrm{SO}_{4}, \mathrm{Br}\right.$, and I) by standard wet chemical techniques (B. Suleymanov et al., 2008) [11]. We also measured the $\mathrm{pH}$ and total dissolved solids (TDS) for each water sample. Both water and sediment samples were analyzed for ${ }^{226} \mathrm{Ra},{ }^{228} \mathrm{Ra}$, and other radionuclides via gamma-spectrometry using a Canberra intrinsic germanium detector. All gamma spectrometric analyses were performed in silicone sealed Marinelli beakers after aging for one month to allow for ingrowth of ${ }^{222} \mathrm{Rn}$ and daughters. The photopeaks from the radon daughters ${ }^{214} \mathrm{~Pb}$ and ${ }^{214} \mathrm{Bi}$ at 295,352 , and $609 \mathrm{keV}$ were used to quantify ${ }^{226} \mathrm{Ra}$ and the ${ }^{228} \mathrm{Ac}$ peaks at 338 and $911 \mathrm{keV}$ were used for ${ }^{228} \mathrm{Ra}$ (Burnett W.C. et al., 2002; Landsberger S. et al., 2013) [12] [13]. Water samples were also analyzed for ${ }^{222} \mathrm{Rn}$ using a RAD-7 radon analyzer (Durridge Co., Inc.) with an attachment (RAD- $\left.\mathrm{H}_{2} \mathrm{O}\right)$ for analyzing radon-in-water. Uncertainties of the chemical measurements average about $5 \%$ and approximately $10 \%$ for the radioactivity measurements.

\section{Results and Discussion}

\subsection{General Situation}

There are 86 wells operating in the immediate area around the formation water lake. These wells are pumping from an average depth of about $700 \mathrm{~m}$ and are recovering a very low grade oil deposit with most pumped fluids having oil content considerably less than $2 \%$. After separation of the oil the formation water is released to the "lake". These formation waters are all very high in total dissolved solids (>70 to $160 \mathrm{~g} / \mathrm{L}$ ). While the in situ temperatures are approximately $60^{\circ} \mathrm{C}$, the water discharged to the lake is about $40^{\circ} \mathrm{C}$ after separation. Approximately $3000 \mathrm{~m}^{3} /$ day accumulates in this manner. When the level of the lake becomes too high, water is pumped into the Caspian Sea. Based on an estimated volume of the lake, the average residence time of the water is on the order of only a few months.

\subsection{Well and Lake Waters}

The formation waters in the lake and well samples are similar in almost all respects (Table 1 \& Table 2). 
Table 1. Concentration of cations and anions in well (W) and lake (L) waters. All samples filtered through a $0.45 \mathrm{~m}$ filter except for the carbonate analyses.

\begin{tabular}{|c|c|c|c|c|c|c|c|c|}
\hline Sample & $\mathrm{Na}$ & K & $\mathrm{Ca}$ & Mg & $\mathrm{Sr}$ & $\mathrm{Ba}$ & Cond & TDS \\
\hline $\mathrm{N}$ & $\mathrm{mol} / \mathrm{L}$ & $\mathrm{mmol} / \mathrm{L}$ & $\mathrm{mmol} / \mathrm{L}$ & $\mathrm{mmol} / \mathrm{L}$ & $\mathrm{mmol} / \mathrm{L}$ & $\mathrm{mmol} / \mathrm{L}$ & $\mathrm{mS} / \mathrm{cm}$ & $\mathrm{g} / \mathrm{l}$ \\
\hline $1 \mathrm{~W}$ & 1.2 & 4.7 & 13 & 9 & 0.4 & 0.07 & 31.0 & 70 \\
\hline $2 \mathrm{~W}$ & 1.2 & 6.4 & 7 & 11 & 0.6 & 0.03 & 33.9 & 73 \\
\hline $3 \mathrm{~W}$ & 2.0 & 5.0 & 126 & 63 & 1.5 & 0.30 & 53.4 & 160 \\
\hline $4 \mathrm{~W}$ & 2.0 & 4.1 & 120 & 47 & 1.3 & 1.30 & 50.1 & 140 \\
\hline $5 \mathrm{~W}$ & 1.1 & 4.8 & 9 & 77 & 0.3 & 0.09 & 30.5 & 70 \\
\hline $6 \mathrm{~W}$ & 2.1 & 5.2 & 130 & 66 & 1.5 & 0.20 & 53.9 & 160 \\
\hline $7 \mathrm{~W}$ & 2.0 & 5.5 & 110 & 67 & 1.3 & 0.10 & 51.0 & 155 \\
\hline $8 \mathrm{~L}$ & 1.3 & 4.4 & 25 & 26 & 0.5 & 0.08 & 34.6 & 80 \\
\hline Sample & $\mathrm{Cl}$ & $\mathrm{SO}_{4}$ & $\mathrm{HCO}_{3}$ & B & I & $\mathrm{pH}$ & Turb & Tot.Org \\
\hline $\mathrm{N}$ & $\mathrm{mol} / \mathrm{L}$ & $\mathrm{mmol} / \mathrm{L}$ & $\mathrm{mmol} / \mathrm{L}$ & $\mu \mathrm{mol} / \mathrm{L}$ & $\mu \mathrm{mol} / \mathrm{L}$ & & NTU & $\mathrm{g} / \mathrm{L}$ \\
\hline $1 \mathrm{~W}$ & 1.3 & 1.5 & 28 & 0.001 & 0.001 & 7.09 & 10 & 1.9 \\
\hline $2 \mathrm{~W}$ & 1.3 & 1.2 & 70 & 0.001 & 0.002 & 6.89 & 40 & 17.5 \\
\hline $3 \mathrm{~W}$ & 2.5 & 0.8 & 11 & 0.011 & 0.001 & 6.63 & 47 & 1.6 \\
\hline $4 \mathrm{~W}$ & 2.3 & 0.7 & 7 & 0.001 & 0.004 & 6.22 & 35 & 3.0 \\
\hline $5 \mathrm{~W}$ & 1.2 & 0.7 & 31 & 0.002 & 0.001 & 7.07 & 15 & 2.0 \\
\hline $6 \mathrm{~W}$ & 2.6 & 1.2 & 12 & 0.001 & 0.001 & 6.34 & 23 & 0.9 \\
\hline $7 \mathrm{~W}$ & 2.4 & 4.0 & 9 & 0.001 & 0.0004 & 6.09 & 54 & 2.2 \\
\hline $8 \mathrm{~L}$ & 1.5 & 1.1 & 13 & 0.006 & 0.005 & 7.30 & 10.8 & 0.2 \\
\hline
\end{tabular}

Table 2. Radionuclides in well (W) and lake (L) waters.

\begin{tabular}{|c|c|c|c|c|c|}
\hline Sample & Well depth & Ra-226 & $\mathrm{Rn}-222$ & Ra-228 & $\mathrm{K}-40$ \\
\hline $\mathrm{N}$ & $\mathrm{m}$ & $\mathrm{Bq} / \mathrm{l}$ & $\mathrm{Bq} / \mathrm{l}$ & $\mathrm{Bq} / \mathrm{l}$ & $\mathrm{Bq} / \mathrm{l}$ \\
\hline $1 \mathrm{~W}$ & 646 & 1.4 & 16 & 2.5 & 3.8 \\
\hline $2 \mathrm{~W}$ & 736 & 1.0 & 10.5 & 2.7 & 5.4 \\
\hline $3 \mathrm{~W}$ & 649 & 2.0 & 45 & 4.5 & 4.3 \\
\hline $4 \mathrm{~W}$ & 577 & 2.4 & 32 & 5.0 & 3.5 \\
\hline $5 \mathrm{~W}$ & 737 & 1.4 & 5.3 & 2.0 & 4.9 \\
\hline $6 \mathrm{~W}$ & 612 & 1.7 & 23 & 4.4 & 3.7 \\
\hline $7 \mathrm{~W}$ & 707 & 2.1 & 16 & 4.2 & 5.7 \\
\hline $8 \mathrm{~L}$ & lake & 2.3 & 6.4 & 3.8 & 11.5 \\
\hline
\end{tabular}

They are all very high in TDS, mainly a sodium chloride brine with secondary calcium bicarbonate. All are in a pH range of 6 - 7. The waters are also very high in radium, with ${ }^{226} \mathrm{Ra}$ activities as high as $2.4 \mathrm{~Bq} / \mathrm{L}$ and ${ }^{228} \mathrm{Ra}$ activities up to $5 \mathrm{~Bq} / \mathrm{L}$. Since "average” groundwater activities are typically around 0.015 Bq/L (Eisenbud and Gesell, 1997) [14], these waters are elevated by over two orders of magnitude. In general, the radium isotopes follow each other (Figure 2) with an average activity ratio of $2.0 \pm 0.4$. 
Both ${ }^{226} \mathrm{Ra}$ and ${ }^{228} \mathrm{Ra}$ tend to be highest in the waters with the highest TDS (Figure 3). The lake water displays an intermediate character in this respect as it does with many of the other characteristics. This may be a result of the relatively low residence time in the lake as this is just temporary storage until the water is pumped into the Caspian Sea.

While it is not clear what is controlling the radium content in these waters, we note that there is a relatively strong inverse relationship to bicarbonate (Figure 4). While there is also an inverse relationship to sulfate, the bicarbonate dependency appears stronger. There is actually a somewhat positive relationship between radium and barium, which is surprising as barite $\left(\mathrm{BaSO}_{4}\right)$ is often thought to control radium solubility.

It may be that there were fine particles of suspended barite in the water samples (samples for gamma spectrometry were filtered through a paper filter to remove oil residues, etc., but fine particles could have passed through). We entered the chemical data for the lake water (sample $8 \mathrm{~L}$ ) into the thermodynamic program MINEQL and it predicted that barium sulfate and calcium carbonate would precipitate. The program calculated that $99.6 \%$ of the $\mathrm{Ba}$ would precipitate out as $\mathrm{BaSO}_{4}$, and $36.6 \%$ of the $\mathrm{Ca}$ as $\mathrm{CaCO}_{3}$. Our chemical results show some $\mathrm{Ba}$ is in solution ( $0.4 \mathrm{~m}$ filtered) so it seems unlikely that such a large fraction precipitated. The radiumbicarbonate relationship (Figure 4), however, suggests that carbonate precipitation in these waters is significant and may be an important control on the radium concentration.

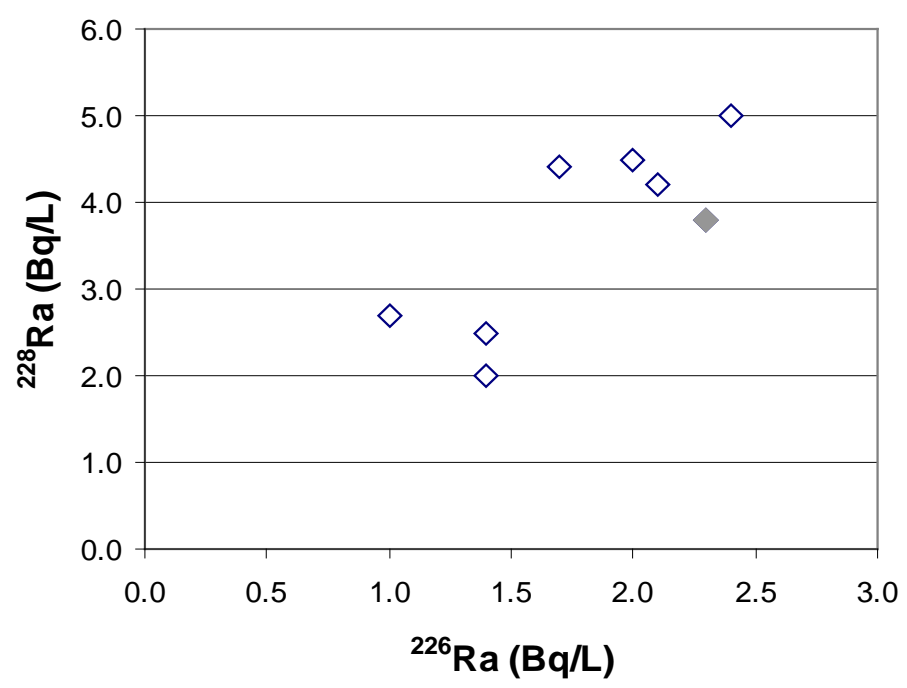

Figure 2. Ra-228 versus ${ }^{226} \mathrm{Ra}$ in well waters and lake water. The open diamonds are well waters and the closed symbol represents the lake water.

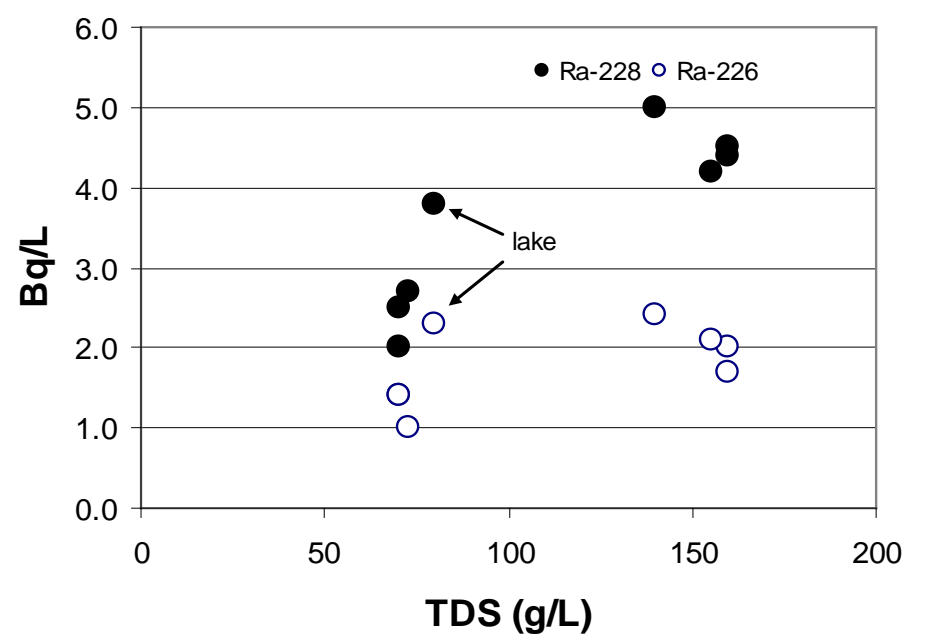

Figure 3. Radium isotopes versus total dissolved solids. 


\subsection{Sediments}

We analyzed radium isotopes from 2-cm thick layers from a sediment core collected in the central portion of the lake in June 2006. All of these samples were analyzed in sealed $\left(\sim 100 \mathrm{~cm}^{3}\right)$ plastic containers using the same gamma spectrometer as the lake waters. The results (Table 3) show that the sediments are somewhat (approximately a factor of 2) enriched in radium compared to typical soils and sediments (Eisenbud and Gesell, 1997; Huck et al., 1989) [14] [15] but not nearly elevated to the same extent as the lake waters.

In addition, the isotopic composition of the sediments is very different from the formation waters with an average activity ratio of $0.89 \pm 0.13$ (formation waters $\mathrm{AR}=2.0 \pm 0.4$ ). In fact, the ARs in the youngest sediments are still lower, around 0.60 . It thus appears that if radium is precipitating and being added to these sediments, the additions must be relatively minor.

When one examines the ${ }^{228 / 228} \mathrm{Ra}$ AR down core, there is a trend of increasing values (Figure 5) until a fairly steady-state level is obtained.

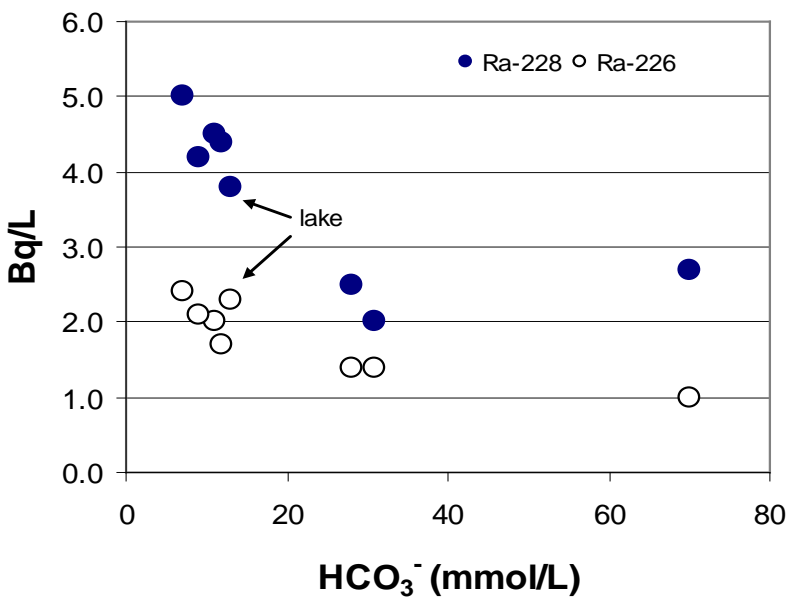

Figure 4. Radium isotopes versus bicarbonate concentration. The outlier at $70 \mathrm{mmol} / \mathrm{L} \mathrm{HCO}_{3}$ may be a result of carbonate particles in suspension that consumed acid during the titration. Samples for carbonate analyses were run unfiltered.

Table 3. Natural radionuclides in sediment layers from a core in the radium lake.

\begin{tabular}{cccccc}
\hline Layer & Pb-210 & Ra-226 & Ra-228 & K-40 & Ra-228/Ra-226 \\
\hline cm & $\mathrm{mBq} / \mathrm{g}$ & $\mathrm{mBq} / \mathrm{g}$ & $\mathrm{mBq} / \mathrm{g}$ & $\mathrm{mBq} / \mathrm{g}$ & 0.6 \\
\hline $0-2$ & 18 & 69 & 42 & 430 & 0.7 \\
$2-4$ & $<1.7$ & 49 & 35 & 450 & 0.8 \\
$4-6$ & 7 & 44 & 36 & 480 & 0.9 \\
$6-8$ & $<1.7$ & 42 & 38 & 650 & 0.9 \\
$8-10$ & 51 & 40 & 36 & 550 & 0.9 \\
$10-12$ & 31 & 35 & 32 & 505 & 1.0 \\
$12-14$ & 60 & 41 & 43 & 570 & 1.0 \\
$14-16$ & 12 & 32 & 32 & 490 & 0.9 \\
$16-18$ & 31 & 38 & 34 & 510 & 0.8 \\
$18-20$ & 35 & 41 & 34 & 560 & 1.0 \\
$20-22$ & 16 & 38 & 38 & 405 & 1.0 \\
$22-24$ & $<1.7$ & 37 & 39 & 620 & 1.1 \\
$24-26$ & 44 & 35 & 39 & 615 & 0.9 \\
\hline
\end{tabular}




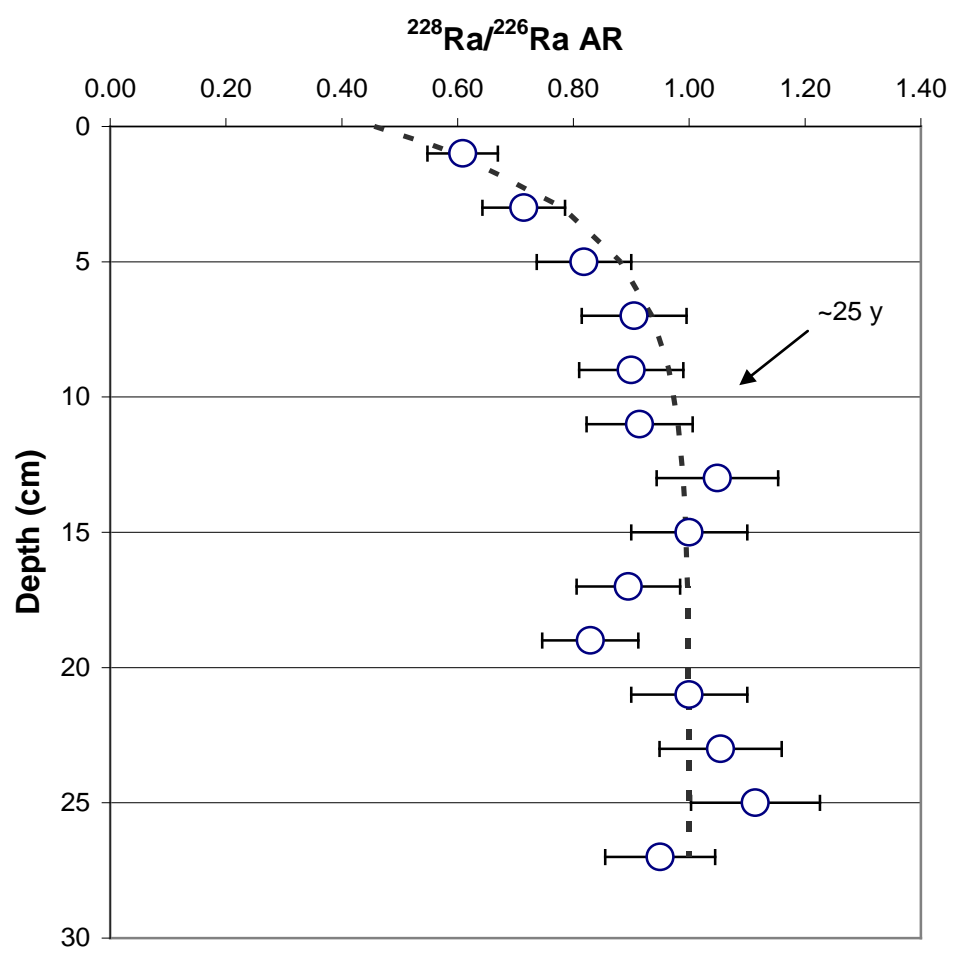

Figure 5. Distribution of the ${ }^{228} \mathrm{Ra} /{ }^{226} \mathrm{Ra}$ activity ratio (AR) with depth in a sediment core from radium lake. The dashed line represents ingrowth assuming that ${ }^{228} \mathrm{Ra}$ was below equilibrium with ${ }^{232} \mathrm{Th}$ in the young sediments near the top and reached equilibrium at a depth around $10 \mathrm{~cm}$.

If this trend is related to in growth of ${ }^{228} \mathrm{Ra}$ into its parent ${ }^{232} \mathrm{Th}$, the 5.7 -year half-life of ${ }^{228} \mathrm{Ra}$ would require about 25 years to reach the quasi-steady-state level at about $10 \mathrm{~cm}$ depth (accumulation rate of $\sim 0.4 \mathrm{~cm} / \mathrm{yr}$ ). Unfortunately, the upper levels of the core do not have any excess ${ }^{210} \mathrm{~Pb}$, so we cannot confirm that age estimate using ${ }^{210} \mathrm{~Pb}$ chronology.

We did verify that the upper two layers in the core (up to $4 \mathrm{~cm}$ ) contained fallout ${ }^{137} \mathrm{Cs}$ so at least these layers are no older than about 40 yrs.

\section{Summary}

The investigated water samples are very high in radium, with ${ }^{226} \mathrm{Ra}$ activities as high as $2.4 \mathrm{~Bq} / \mathrm{L}$ and ${ }^{228} \mathrm{Ra}$ activities up to $5 \mathrm{~Bq} / \mathrm{L}$. Both ${ }^{226} \mathrm{Ra}$ and ${ }^{228} \mathrm{Ra}$ tend to be the highest in the waters with the highest TDS. There is actually a somewhat positive relationship between radium and barium, which is surprising as barite $\left(\mathrm{BaSO}_{4}\right)$ is often thought to control radium solubility. There is a relatively strong inverse relationship to bicarbonate and sulfate, and the bicarbonate dependency appears stronger. The radium-bicarbonate relationship, however, suggests that carbonate precipitation in formation waters is significant and may be an important control on the radium concentration.

When one examines the ${ }^{228 / 228} \mathrm{Ra}$ AR down core, there is a trend of increasing values until a fairly steadystate level is obtained. If this trend is related to ingrowth of ${ }^{228} \mathrm{Ra}$ into its parent ${ }^{232} \mathrm{Th}$, the 5.7 -year half-life of ${ }^{228} \mathrm{Ra}$ would require about 25 years to reach the quasi-steady-state level at about $10 \mathrm{~cm}$ depth (accumulation rate of $\sim 0.4 \mathrm{~cm} / \mathrm{yr}$ ). We did verify that the upper two layers in the core (up to $4 \mathrm{~cm}$ ) contained fallout ${ }^{137} \mathrm{Cs}$ so at least these layers are no older than about 40 yrs.

Investigation of radium isotopes $\left({ }^{226} \mathrm{Ra}\right.$ and $\left.{ }^{228} \mathrm{Ra}\right),{ }^{137} \mathrm{Cs}$ and useful parameters of formation water give important information about history and origin of NORM contamination. The radium-bicarbonate relationship may be an important control on the radium concentration, without expensive radionuclide analyses.

\section{Acknowledgements}

The authors' sincere thanks are due to Dr Burnett W. C., from Florida State University, USA for his essential 
advice provided throughout this work.

\section{References}

[1] Wilson, A.J. and Scott, M.L. (1992) Characterization of Radioactive Petroleum Piping Scale with an Evaluation of Subsequent Land Contamination. Health Physics, 63, 681-685. http://dx.doi.org/10.1097/00004032-199212000-00009

[2] Mackay, E.J. and Heriot-Watt, U. (2003) Modeling In-Situ Scale Deposition: The Impact of Reservoir and Well Geometries and Kinetic Reaction Rates. February Edition, Society of Petroleum Engineers.

[3] Efendiyev, G.H. (1953) The Radioactivity of the Mineral Waters of Azerbaijan. Baku, 44.

[4] Bernhardt, D.E., Owen, D.H. and Rogers, V.C. (1996) Assessment of NORM in Pipe from Oil and Gas Production. In: Proceedings of the 29th Midyear Tropical Meeting of the Health Physics Society, Madison, 7-10 January 1996, 133-138.

[5] Smith, K.P., Blunt, D.L., Williams, G.P. and Tebes, C.L. (1996) Radiological Dose Assessment Related to Management of Naturally Occurring Radioactive Materials Generated by the Petroleum Industry. ANL/EAD-2, Argonne National Laboratory, Argonne. http://dx.doi.org/10.2172/414355

[6] Tomson, M.B., Kan, A.T., Fu, G. and Al-Thubaiti, M. (2003) NORM Scale Formation, Control, and Relation to Gas Hydrate Control. Report from 10th Annual International Petroleum Conference, IPEC, Tulsa.

[7] Wiegand, J.W. and Sebastian, F. (2002) Origin of Radium in High-Mineralized Waters. IAEA-TECDOC-1271, IAEA, Vienna.

[8] Doerner, H.A. and Hoskins, W.M. (1925) Co-Precipitation of Radium and Barium Sulfates. Journal of the American Chemical Society, 47, 662-675. http://dx.doi.org/10.1021/ja01680a010

[9] Zielinski, R.A., Otton, J.K. and Budahn, J.R. (2001) Use of Radium Isotopes to Determine the Age and Origin of Radioactive Barite at Oil-Field Production Sites. Environmental Pollution, 113, 299-309. http://dx.doi.org/10.1016/S0269-7491(00)00188-3

[10] Alizadeh, A.A., Akhmedov, G.A., Aliev, A.K. and Zeynalov, M.M. (1966) Geology Oil and Gas Fields in Azerbaijan. Academy Science, 392s.

[11] Suleymanov, B., Ahmedov, M., Humbatov, F. and Ibadov, N. (2008) Hazardous Pollutant Database for Kura-Araks Water Quality Management. In: Moerlins, J.E., Khankhasayev, M.K., Leitman, S.F. and Makhmudov, E.J., Eds., Transboundary Water Resources: A Foundation for Regional Stability in Central Asia, Springer, Netherlands, 171-182. http://dx.doi.org/10.1007/978-1-4020-6736-5_12

[12] Burnett, W.C., et al. (2002) Assessing Methodologies for Measuring Groundwater Discharge to the Ocean. EOS, 83, 117-123. http://dx.doi.org/10.1029/2002EO000069

[13] Landsberger, S., Brabeca, C., Caniona, B., Hashema, J., Lua, C., Millsapa, D. and Georgeb, G. (2013) Determination of 226Ra, 228Ra and 210Pb in NORM Products from Oil and Gas Exploration: Problems in Activity Underestimation Due to the Presence of Metals and Self-Absorption of Photons. Journal of Environmental Radioactivity, 125, 23-26. http://dx.doi.org/10.1016/j.jenvrad.2013.02.012

[14] Eisenbud, M. and Gesell, T.P. (1997) Environmental Radioactivity from Natural, Industrial, and Military Sources. 4th Edition, Academic Press, New York, 656 p.

[15] Huck, P.M., McClymont, G.L., Schwartz, F.W., Nesbitt, B.E., Anderson, W.B. and Kratochvil, B. (1989) Modeling of Radium-226 Leaching from Barium-Radium Sulfate Sludges. Waste Management, 9, 157-163. http://dx.doi.org/10.1016/0956-053X(89)90076-7 


\section{Submit or recommend next manuscript to SCIRP and we will provide best service for you:}

Accepting pre-submission inquiries through Email, Facebook, LinkedIn, Twitter, etc.

A wide selection of journals (inclusive of 9 subjects, more than 200 journals)

Providing 24-hour high-quality service

User-friendly online submission system

Fair and swift peer-review system

Efficient typesetting and proofreading procedure

Display of the result of downloads and visits, as well as the number of cited articles

Maximum dissemination of your research work

Submit your manuscript at: http://papersubmission.scirp.org/ 